\title{
STRATEGIC CORPORATE SOCIAL RESPONSIBILITY AND SUSTAINABILITY OF MULTINATIONAL CORPORATIONS IN NIGERIA
}

\author{
DOI: 10.17261/Pressacademia.2021.1397 \\ RJBM- V.8-ISS.2-2021(1)-51-61
}

\author{
Emmanuel A. Ivwurie ${ }^{1}$, Ekom Etim Akpan ${ }^{2}$ \\ ${ }^{1}$ University of Nigeria, Doctoral Scholar, Department of Management, Enugu Campus, Nigeria. \\ ivwurieee@hotmail.com,DOI: 0000-0003-4554-1751 \\ ${ }^{2}$ University of Nigeria, Doctoral Scholar, Department of Management, Enugu Campus, Nigeria. \\ akpan.ekom.pg.79821@unn.edu.ng,DOI: 0000-0002-5501-0180
}

\begin{tabular}{l}
\hline Date Received: February 14, $2021 \quad$ Date Accepted: May 16, 2021 \\
\hline To cite this document \\
Ivwurie, E.A., Akpan, E.E. (2021). Strategic corporate social responsibility and organisational sustainability of multinational corporations in Nigeria. \\
Research Journal of Business and Management (RJBM), 8(2), 51-61. \\
Permanent link to this document: $\frac{\text { http://doi.org/10.17261/Pressacademia.2021.1397 }}{\text { Copyright: Published by PressAcademia and limited licensed re-use rights only. }}$ \\
Copsis
\end{tabular}

\section{ABSTRACT}

Purpose- This paper aims at proffering solutions to the problem of unsustainable practices by multinationals in Nigeria, especially those operating in the oil-rich Niger Delta region. The study looks at strategic corporate social sustainability and how it affects organisational sustainability.

Methodology- The cross sectional research design was followed in this study, while judgmental and snow-balling sampling techniques were used in the process of collecting data. Strategic corporate social responsibility was observed through philanthropic, ethical and legal responsibilities, while organizational sustainability was measured using economic, environmental and social sustainability.

Findings- Results of analyses showed that, and philanthropic, ethical and legal responsibilities significantly affected economic environmental, and social sustainability.

Conclusion- The study empirically proved that, strategic corporate social responsibility influences organisational sustainability positively, therefore multinational corporations should take corporate social responsibility seriously.

Keywords: Strategic corporate social responsibility, organisational sustainability, philanthropic responsibility, ethical responsibility, legal responsibility.

JEL Codes: M14, M16

\section{INTRODUCTION}

Organisational sustainability is one of the most discussed concepts in business gatherings, especially during international business consultations (Elkington, 1999). In the last two decades the concept has gradually become the crux of deliberations among business executives and stakeholders. Organisational sustainability is mostly considered using environment, economic and social sustainability (Khan, Dewan \& Chowdhury, 2014). In terms of economic sustainability, firms thrive to achieve it because it is a catalyst to sustained profitability and survival of the firm. Environmental sustainability ensures the realisation of business today's aspirations without destroying the natural environment (Martínez \& del Bosque, 2013; Wakhare \& Borhade, 2018). On the other hand, social sustainability ensures cordial relationship between the firm and its host community (Khan, Dewan \& Chowdhury, 2014).

Also, organisational sustainability advocates that organisations should focus on the triple bottom line (economic, environment and social) rather than on economic factors alone. Thus, this ensures that organisations give consideration not only to economic issues but focus on environmental and societal issues as well. This shows that, organisational sustainability is extremely important to the organisation's wellbeing and its viability.

On the other hand, strategic corporate social responsibility or "strategic philanthropy" (Carroll, 2001, p. 200) is done to accomplish strategic business goals. It is generally believed that good social behaviour endears a business to the society it operates in (Orlitzky, 
Siegel \& Waldman, 2011). That is, the practice of giving back to the society which is the core purpose of strategic corporate social responsibility is to serve the best interests of the business (Quester \& Thompson, 2001). This is because corporate social responsibility promotes good understanding between management and society, thereby achieving the organisational goal of stakeholders' satisfaction (Orlitzky \& Swanson, 2008).

Focusing on social goals may not appear profitable in the interim. However, a view on the long term perspective shows that the firm stands to leverage on the trust it builds with the wider society by increasing its market-base and command loyalty from local community, which its competitors may not be able to afford (Park, Shin, \& Kim, 2019). This results in sales growth, profitable and improved company reputation, ending with maximization of shareholders' wealth (Hosmer, 1995; Jones, 1995; McWilliams, Siegel \& Wright, 2006; Gardberg, Zyglidopoulos, Symeou \& Schepers, 2017).

Studies have been conducted on the relationship between corporate social responsibility and firm sustainability (e.g. Werther Jr. \& Chandler, 2005; Fontaine, 2013; Oyewole \& Adewale, 2016; Borhade \& Wakhare, 2018). Others have also studied the impact of CSR on other organisational outcomes such as employee motivation (e.g. Kim \& Scullion, 2013), employee satisfaction (e.g. Bauman \& Skitka, 2012), customer loyalty (e.g. Pérez \& del Bosque, 2015). Despite the avalanche of studies in this area, there is still a lot of controversy in Nigeria on the subject of sustainability, especially in the Niger Delta region where multinational corporations have been accused of exploiting the natural resources from the area without adequately compensating the host communities (Ndu \& Agbonifoh, 2014).

Thus, this study will empirically examine the nexus between CSR and organisational sustainability in the Nigerian work environment, especially the multinational corporations operating in Port Harcourt, Rivers State.

\section{LITERATURE REVIEW}

\subsection{Strategic Corporate Social Responsibility}

Strategic corporate social responsibility became popular in the 1980s (Jones, 1997). The CSR ideology is that, organisations will gain tremendously in the future by being socially responsible to the society where they operate and maintaining a high ethical conduct in their day to day activities, however, in the short run it cost a lot to be socially responsible. As submitted by Vaughn $(1999$, p. 199) money spent on CSR activities should be acknowledged as "investments in a goodwill bank", and produces great financial benefits (McWilliams \& Siegel, 2001).

The benefits associated with CSR might not reflect instantly on a company's balance sheet which is the case with other forms of investments such as advertising, marketing research. However, in the long-run, the good will generated by being socially responsible might have more value than these other investments. Geoffrey (2001) submitted that "the goodwill generated among customers, government regulators, and consumer advocates from such efforts might likely justify the investment".

Among the several definition of CSR is that of The European Foundation for Quality Management (EFQM), which sees CSR as "a whole range of fundamentals that organisations are expected to acknowledge and to reflect in their actions. It includes respecting human rights, fair treatment of the workforce, customers and suppliers, being good corporate citizens of the communities in which they operate and conservation of the natural environment". They further explained that, these fundamentals should not only be seen as ethically and morally desirable, they should be embedded in the company's philosophy, by so doing society will allow the company to survive in the long term since it benefits from the company's activities (EFQM, 2004).

Likewise, Kotler and Armstrong (2015, p. 136), define CSR as "a commitment to enhance community well-being via discretionary business practices and contributions of corporate resources". While, Wood (2010) submits that corporate social responsibility is "a set of descriptive of business activity, focusing on the impacts and outcomes for society, stakeholders and the firm". The European Commission (2002) sees CSR as giving a deliberate attention to social and environmental issues in a company's policy framework. This implies that corporations have to adopt the triple bottom line approach in their business activities rather than giving attention to only economic aspect but also social and environmental aspects (Martínez \& del Bosque, 2013; Pérez \& del Bosque, 2015). Furthermore, EFQM (2004) noted that, economic responsibility involves "integrity, corporate governance, economic development of the community, transparency, prevention of bribery and corruption, payments to national and local authorities, use of local suppliers, hiring local labour", while social obligation includes "human rights, labour rights, training and developing local labour, contributing expertise to community programs and similar". Lastly, environment responsibility includes "precautionary approaches to prevent or minimise adverse impacts, support for initiatives promoting greater environmental responsibility, developing and diffusing environmentally friendly technologies and similar".

Common characteristics of CSR as presented by EFQM are shown in Table 1 below 
Table 1: Common Characteristics of CSR

\begin{tabular}{|c|l|}
\hline S/N & Characteristics \\
\hline 1 & $\begin{array}{l}\text { Meeting the need of current stakeholders without compromising the ability of future generations to meet their own } \\
\text { demand }\end{array}$ \\
\hline 2 & $\begin{array}{l}\text { Adopting CSR voluntarily, rather than as legal requirement, because it is seen to be in the long-term interests of the } \\
\text { organization }\end{array}$ \\
\hline 3 & Integrating social, environmental and economic policies in day-to-day business \\
\hline 4 & Accepting CSR as a core activity that is embedded into an organisation's management strategy \\
\hline
\end{tabular}

Source: European Foundation for Quality Management, 2004.

In this work, strategic corporate social responsibility is segmented in terms of philanthropic, ethical and legal responsibilities. These dimensions were adopted from Montazeri, Talebpour, Andam and Kazemnejad (2017).

\subsection{The Concept of Organisational Sustainability}

Organisational sustainability is a recurring concept in management literature and gradually becoming a watchword for business managers and operators all over the world (Bachman, Bashyal \& Baumann, 2012; Rosen \& Kishawy, 2012; Peter, Daphne \& David, 2014). Sustainability has been shown to have impact on all sectors of the economy, industries and individual organizations, not minding whatever type of product or services they produce or render. Seetha (2009) submits that firms are losing goodwill from the populace because of the increasing unfriendly and unhealthy environmental practices such as disposing industrial wastes in the environment and causing untold environmental harm. Hence, sustainability appears to be very strategic to the survival and competitiveness of manufacturing firms. The wish to be sustainable has forced some manufacturing firms to strive to improve their product quality, reduce material wastes, and continuously expand their market-share (Nambiar, 2010; Bashyal, Bachman \& Baumann, 2011). Also, management commitment to deliver on the triple bottom line, has led to organisational sustainability becoming a focal point for multinational enterprises. The desire of these firms to produce products that will not only help them maintain their economic goals but also fulfill their environmental and social responsibilities is growing by the day (Bashyal, Bachman \& Baumann, 2011).

Among the numerous definition of sustainability is that of World Commission on Environment and Development (1987), which stated that sustainability "is development that meets the needs of the present without compromising the ability of future generations to meet their own needs". Organisational sustainability is studied in three facets, which are economic, environmental, and social sustainability (Khan, Dewan \& Chowdhury, 2014). Organizational sustainability promotes the firm's ability to achieve its objectives, be profitable and be held as a socially responsible organization (Crane \& Matten, 2004).

Therefore, organizational sustainability is the production of goods and services today without compromising the future production. Environmental sustainability focuses on the ecosystem, organisational activities are carried out in such a way that physical resources are retained for future generation. On the other hand, economic sustainability is concerned with the economic wellbeing of the business. Economic sustainability includes the firm's ability to meet its short term obligations without mortgaging the company's future. Lastly, social sustainability focuses on ensuring social justice (Crane \& Matten, 2004).

\subsection{Strategic corporate social responsibility and Organisational Sustainability}

Multinational corporations are often persuaded by stakeholders to undertake social responsibilities (Orlitzky, et al., 2011). This has increased scholars and management practitioners' interests in the CSR concept, and how it affects sustainability of firms; especially multinational organisations. Despite the raging debates on the relationship between these variables, the results from these studies appears inconsistent, prompting further inquiry into the relationship between the two concepts (Orlitzky, et al., 2011).

In a study that was focused on multinational businesses, Orlitzky, et al (2011) found that discretionary CSR activities have the ability to boost a company's competitiveness and promote the brand reputation, which finally leads to better economic and financial performance. 
In an earlier study, Hermann (2004) noted that the issue of CSR and sustainable development cannot be pushed under because of the steady growth of global businesses. The activities of the firms have adverse effects on the environment and as such they must devised means of ameliorating these negative effects on the environment and society at large. This was in consonance with the views of Elisa (2002), who submitted that "the premise of the corporate social responsibility movement is that corporations, because they are the dominant institution of the planet, must squarely face and address the social and environmental problems that afflict humankind". Thus CSR is a possible solution to right the wrongs done to the environment and stakeholders generally, which when achieved promotes organisational sustainability.

Furthermore, Hermann (2004) observed that "corporate social responsibility is a potential solution that could lead to the achievement of sustainable development". He concluded that "corporate social responsibility is an initiative that has been touted as a possible remedy for the ills of globalisation that hinder the realisation of sustainable development - that is inequities in wealth, environmental degradation, and unfair labor practices that are endemic of globalisation".

There is however differing opinion about the effect of CSR on organisational sustainability, with some scholars believing that the most significant social responsibility of a business is to make profit for the shareholders (Levitt, 1958; Friedman, 1970; Jensen, 2002); Dan-Jumbo \& Akpan, 2018). Leading the side of the debate is Friedman (1970), who submitted that "business of business is business", meaning that businesses are there to realise profits and not to involve in social duties. Still others note that, there is enormous economic benefit in satisfying stakeholders' economic, environmental and societal needs (Freeman, 1984; Jones, 1995).

These inconsistencies and lack of agreement on the effect of CSR on organisational sustainability informed the need for this study. To examine the relationship between these two variables, a conceptual framework is developed as shown in Figure 1, and research hypotheses formulated.

Figure 1: Proposed Relationships between Dimensions of Strategic CSR and Org. Sustainability

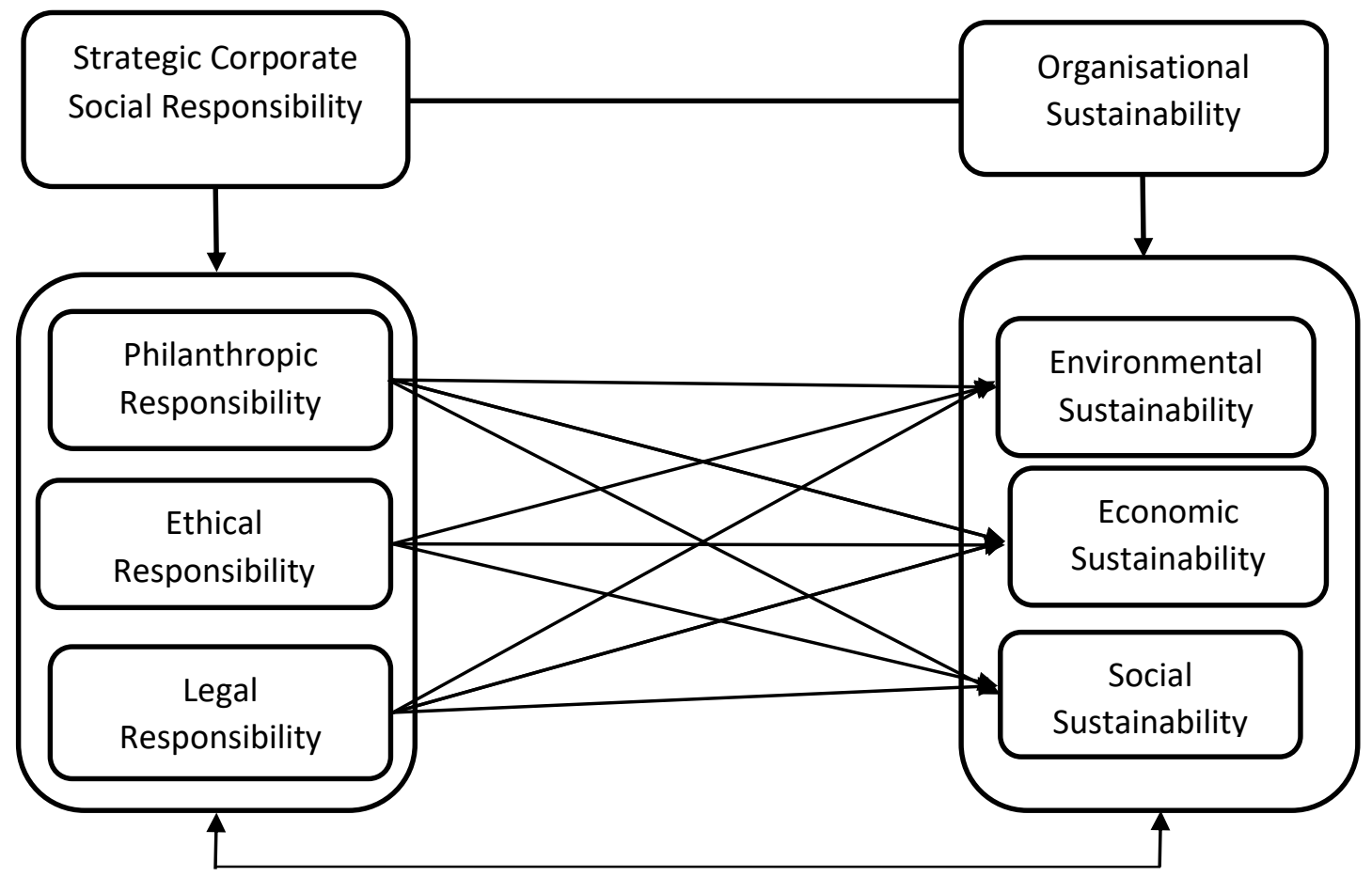

The following research hypotheses were formulated:

H1a: Philanthropic responsibility has significant effect on environmental sustainability

$\mathrm{H} 1 \mathrm{~b}$ : Ethical responsibility has significant effect on environmental sustainability

$\mathrm{H} 1 \mathrm{c}$ : Legal responsibility has significant effect on environmental sustainability

H2a: Philanthropic responsibility has significant effect on economic sustainability

$\mathrm{H} 2 \mathrm{~b}$ : Ethical responsibility has significant effect on economic sustainability 
$\mathrm{H} 2 \mathrm{c}$ : Legal responsibility has significant effect on economic sustainability

H3a: Philanthropic responsibility has significant effect on social sustainability

$\mathrm{H} 3 \mathrm{~b}$ : Ethical responsibility has significant effect on social sustainability

H3c: Legal responsibility has significant effect on social sustainability

\section{METHODOLOGY}

The cross sectional research design was followed in this study. This is because the study was concerned with the collection of data on constructs at a single period of time (Kesmodel, 2018). The population of study was made up of multinational corporations in Port Harcourt. The judgmental and snow-ball sampling techniques were used in the process of collecting data for the study. Respondents in this study include Senior Executives, Managers and other personnel in position of authority in the firms. There classes of respondents were chosen because they are in the know about their organisation's efforts and policies pertaining to CSR.

Due to the busy schedule of the respondents, the questionnaire was sent via email and social media platforms to those that could not be accessed face-to-face. While others also suggested their colleagues who they believed were knowledgeable about the concepts under study. After the whole process, a total of 354 copies of the questionnaire were retrieved. The respondents cut across several sectors of the economy such as oil servicing, telecommunications, banking and manufacturing.

Measurements of variables - The instrument for this study was designed with the sole purpose of eliciting responses from respondents on the two constructs under review. The instrument was divided into three sections. Section A comprises items on the demographic details of the respondents. Section B, was concerned with the independent variable - strategic corporate social responsibility, it was made up of 13 items, among which include "my organisation supports cultural and social events in the community; my organisation gives financial and non-financial support to Non-Governmental Organisations". These statement items were adopted from Montazeri, et al (2017), and adjusted to suit the local work setting.

The last section comprises items describing organisational sustainability. It has a total of 13 items including "our firm's economic performance is at an acceptable level in terms of sales growth; our firm's economic performance is at an acceptable level in terms of income stability". These items were adopted from Khan, Dewan and Chowdhury (2014). Preliminary tests were conducted on the data to ascertain its reliability and validity. The reliability of this study's instrument was confirmed through the use of the Cronbach Alpha. Each dimension and measure returned alpha value of .70 and above (Nunnaly, 1978). On the other hand, content validity was ensured by adopted previously validated scales.

\section{RESULTS AND DISCUSSIONS}

Multiple regression statistical technique was used in testing the research hypotheses. Multiple regression was suitable because it shows the strength of the effect of predictor variables on the criterion variable. In other words, it shows the contribution of each independent variable to the variation in the dependent variable. The analyses were carried out using SPSS version 25.

\section{Test of Hypotheses 1a-c}

H1a: Philanthropic responsibility has significant effect on environmental sustainability

$\mathrm{H} 1 \mathrm{~b}$ : Ethical responsibility has significant effect on environmental sustainability

H1c: Legal responsibility has significant effect on environmental sustainability

Table 2a: Model Summary ${ }^{\mathrm{b}}$

\begin{tabular}{|c|c|c|c|c|}
\hline Model & $\mathrm{R}$ & $\mathrm{R}$ Square & Adjusted R Square & Std. Error of the Estimate \\
\hline 1 & $.612^{\mathrm{a}}$ & .375 & .365 & .768 \\
\hline
\end{tabular}

a. Predictors: (Constant), Philanthropic Responsibility, Ethical Responsibility, Legal Responsibility

b. Dependent Variable: Environmental Sustainability

Table 2b: ANOVA

\begin{tabular}{|ll|c|c|c|c|c|}
\hline Model & & Sum of Squares & Df & Mean Square & F & Sig. \\
\hline \multirow{2}{*}{1} & Regression & 64.775 & 3 & 21.592 & 36.568 & $.000^{\mathrm{b}}$ \\
& Residual & 108.054 & 183 & .590 & & \\
& Total & 172.830 & 186 & & & \\
\hline
\end{tabular}

a. Dependent Variable: Environmental Sustainability

b. Predictors: (Constant), Philanthropic Responsibility, Ethical Responsibility, Legal Responsibility 
Table 2c: Coefficients ${ }^{\mathrm{a}}$

\begin{tabular}{|c|c|c|c|c|c|c|}
\hline \multirow[t]{2}{*}{ Model } & & \multicolumn{2}{|c|}{ Unstandardized Coefficients } & \multirow{2}{*}{$\begin{array}{c}\begin{array}{c}\text { Standardized } \\
\text { Coefficients }\end{array} \\
\text { Beta }\end{array}$} & \multirow[t]{2}{*}{$\mathrm{T}$} & \multirow[t]{2}{*}{ Sig. } \\
\hline & & B & Std. Error & & & \\
\hline \multirow{4}{*}{1} & (Constant) & 1.654 & .805 & & 2.055 & .041 \\
\hline & Legal Responsibility & .270 & .031 & .570 & 8.682 & .000 \\
\hline & Ethical Responsibility & .054 & .091 & .040 & .593 & .024 \\
\hline & Philanthropic Responsibility & .161 & .021 & .491 & 7.537 & .000 \\
\hline
\end{tabular}

a. Dependent Variable: Environmental Sustainability

Tables 2a-c show correlation and regression analyses between environmental sustainability and the dimensions of strategic corporate social responsibility (SCSR). Each of the dimensions of SCSR is positively significantly correlated with environmental sustainability $\left(R^{2}=.375, F(3,183)=36.568, p<.001\right)$, revealing that higher SCSR leads to better environmental sustainability. As observed in table $2 \mathrm{c}$, legal responsibility had positive regression values, indicating that companies who are legally responsible are expected to be environmentally sustainable, after controlling for ethical and philanthropic responsibilities. Ethical and philanthropic responsibilities were also positive significantly correlated with environmental sustainability. This finding shows that, all dimensions of SCSR contribute to the multiple regression model. However, a look at the beta values reveal that legal responsibility made the strongest contribution to this model (.270), followed by philanthropic responsibility (.161). Ethical responsibility made the least contribution (.054).

Test of hypotheses $2 a-c$

H2a: Philanthropic responsibility has significant effect on economic sustainability

$\mathrm{H} 2 \mathrm{~b}$ : Ethical responsibility has significant effect on economic sustainability

$\mathrm{H} 2 \mathrm{c}$ : Legal responsibility has significant effect on economic sustainability

Table 3a: Model Summary

\begin{tabular}{|c|c|c|c|c|}
\hline Model & R & R Square & Adjusted R Square & Std. Error of the Estimate \\
\hline 1 & $.598^{\mathrm{a}}$ & .357 & .347 & 3.477 \\
\hline
\end{tabular}

a. Predictors: (Constant), Philanthropic Responsibility, Legal Responsibility, Ethical Responsibility

b. Dependent Variable: Economic Sustainability

Table 3b: ANOVA ${ }^{a}$

\begin{tabular}{|cl|c|c|c|c|c|}
\hline \multicolumn{2}{|c|}{ Model } & Sum of Squares & Df & Mean Square & F & Sig. \\
\hline \multirow{2}{*}{1} & Regression & 1230.446 & 3 & 410.149 & 33.926 & $.000^{\mathrm{b}}$ \\
& Residual & 2212.390 & 183 & 12.090 & & \\
& Total & 3442.836 & 186 & & & \\
\hline
\end{tabular}

a. Dependent Variable: Economic Sustainability

b. Predictors: (Constant), Philanthropic Responsibility, Legal Responsibility, Ethical Responsibility

Table 3c: Coefficients ${ }^{\mathrm{a}}$

\begin{tabular}{|c|c|c|c|c|c|c|}
\hline \multirow{2}{*}{\multicolumn{2}{|c|}{ Model }} & \multicolumn{2}{|c|}{ Unstandardized Coefficients } & \multirow{2}{*}{$\begin{array}{c}\text { Standardized } \\
\text { Coefficients }\end{array}$} & \multirow[t]{2}{*}{$\mathrm{T}$} & \multirow[t]{2}{*}{ Sig. } \\
\hline & & B & Std. Error & & & \\
\hline \multirow{4}{*}{1} & (Constant) & 11.664 & 3.642 & & 3.203 & .002 \\
\hline & Legal Responsibility & .397 & .141 & .661 & 9.928 & .000 \\
\hline & Ethical Responsibility & .026 & .414 & .335 & 4.900 & .000 \\
\hline & Philanthropic Responsibility & .155 & .097 & .106 & 1.600 & .011 \\
\hline
\end{tabular}

a. Dependent Variable: Economic Sustainability 
Tables 3a-c contain result of multiple regression predicting economic sustainability from legal, ethical and philanthropic responsibilities. The results reveal that, legal, ethical and philanthropic responsibilities significantly predicted economic sustainability $\left(R^{2}=.357, F(3,183)=33.926, p<.001\right)$, Also, all three predictor variables added statistically significantly to the model, $p<.05$. However, a look at the beta values reveal that legal responsibility made the strongest contribution to this model (.397), followed by philanthropic responsibility (.155). Ethical responsibility made the least contribution (.026).

\section{Test of hypotheses 3a-c}

H3a: Philanthropic responsibility has significant effect on social sustainability

$\mathrm{H} 3 \mathrm{~b}$ : Ethical responsibility has significant effect on social sustainability

H3c: Legal responsibility has significant effect on social sustainability

Table 4a: Model Summary ${ }^{b}$

\begin{tabular}{|c|c|c|c|c|}
\hline Model & $\mathrm{R}$ & $\mathrm{R}$ Square & Adjusted R Square & Std. Error of the Estimate \\
\hline 1 & $.731^{\mathrm{a}}$ & .534 & .527 & 5.290 \\
\hline
\end{tabular}

a. Predictors: (Constant), Philanthropic Responsibility, Legal Responsibility, Ethical Responsibility

b. Dependent Variable: Social Responsibility

Table 4b: ANOVAa

\begin{tabular}{|ll|c|c|c|c|c|}
\hline Model & & Sum of Squares & Df & Mean Square & F & Sig. \\
\hline \multirow{2}{*}{1} & Regression & 5873.047 & 3 & 1957.682 & 69.954 & $.000^{\mathrm{b}}$ \\
& Residual & 5121.308 & 183 & 27.985 & & \\
& Total & 10994.355 & 186 & & & \\
\hline
\end{tabular}

a. Dependent Variable: Social Responsibility

b. Predictors: (Constant), Philanthropic Responsibility, Legal Responsibility, Ethical Responsibility

Table 4c: Coefficients ${ }^{\mathrm{a}}$

\begin{tabular}{|c|c|c|c|c|c|c|}
\hline \multirow{2}{*}{\multicolumn{2}{|c|}{ Model }} & \multicolumn{2}{|c|}{ Unstandardized Coefficients } & \multirow{2}{*}{$\begin{array}{c}\begin{array}{c}\text { Standardized } \\
\text { Coefficients }\end{array} \\
\text { Beta }\end{array}$} & \multirow[t]{2}{*}{$\mathrm{T}$} & \multirow[t]{2}{*}{ Sig. } \\
\hline & & B & Std. Error & & & \\
\hline \multirow{4}{*}{1} & (Constant) & 9.201 & 5.541 & & 1.660 & .099 \\
\hline & Legal Responsibility & .254 & .214 & .597 & 10.530 & .000 \\
\hline & Ethical Responsibility & .086 & .629 & .193 & 3.315 & .001 \\
\hline & Philanthropic Responsibility & .186 & .147 & .071 & 1.266 & .007 \\
\hline
\end{tabular}

a. Dependent Variable: Social Responsibility

Tables 4a-c contain result of multiple regression predicting economic sustainability from legal, ethical and philanthropic responsibilities. The results reveal that, legal, ethical and philanthropic responsibilities significantly predicted economic sustainability $\left(R^{2}=.534, F(3,183)=69.954, p<.001\right)$, All three predictor variables added statistically significantly to the model, $p$ $<.05$. A look at each variable's beta value reveal that legal responsibility made the strongest contribution to this model (.254), followed by philanthropic responsibility (.186), while ethical responsibility made a least contribution (0.86) to the model.

Discussions - In this study, we empirically examined the nexus between strategic corporate social responsibility and organisational sustainability of multinational corporations in Nigeria. The analysis revealed that the dimensions of strategic corporate social responsibility - philanthropic, ethical and legal responsibilities are positively correlated with the measures of organisational sustainability - economic, environmental and social sustainability. This shows that, for multinational businesses to be sustainable in a developing country such as Nigeria, they have to incorporate social responsibility issues into their day-to-day operations.

In an earlier survey, Fontaine (2013) found a similar result in a study on CSR and sustainability, he concluded that "sustainable business success and shareholder value cannot be achieved solely through maximising short-term profits but instead through market-oriented yet responsible behaviour". Similarly, Hermann (2004) when examining CSR and sustainable development from MNCs perspective, opined that MNCs in an attempt to achieve economic growth, causes harm to the environment. Therefore, they (MNCs) should be involved in social duties and maintained labour standards. 
Still, Mahajan (2011) opines that firm's policy on CSR contributes to sustainable development. This is achieved by administering their operations with the hope to boost business growth and enhance competitiveness at the same time, not jeopardising the environment and advancing social responsibility; including stakeholders' interest.

The finding in the study is also in concordance with the submission of Orlitzky, Siegel and Waldman (2011) in their study "strategic corporate social responsibility and environmental sustainability", and noted that "ecological sustainability could become the central social responsibility challenge for business". Therefore, MNCs must be socially responsible if they want to be competitive and achieve sustainable business growth.

\section{CONCLUSION AND RECOMMENDATIONS}

The study empirically proved that, strategic corporate social responsibility influences organisational sustainability positively, therefore MNCs should take CSR seriously. Thus, it was concluded that, there is a positive relationship between strategic corporate social responsibility and organisational sustainability among MNCs in Nigeria.

The following recommendations are given based on the finding:

i. Multinational corporations should give support during cultural and other social occasions in the host communities. Also, they should introduce health and wellness programmes in the communities. This will improve their philanthropic responsibility.

ii. The MNCs should imbibe the spirit of fair play when competing for scarce resources, while maintaining ethical norms that the society requires. They should avoid unethical behaviour and be accountable to all stakeholders.

iii. Lastly, rules and regulations should be obeyed. The rights of each shareholder should be treated as important. Legal standards should be met. These actions will ultimately result to organisational sustainability.

\section{REFERENCES}

Bachman, B. J., Bashyal, S. \& Baumann, M. (2012). Sustainability in the plastics industry: concerns, issues, and strategies, Polimeri, 33(1), 6-11.

Bashyal, S., Bachman, B. \& Baumann, M. H., (2011). Plastic packaging: acurrent perspective on sustainability. Faculty Research \& Creative Works. Paper 666. http://scholarsmine.mst.edu/faculty_work/666.

Bauman, C.W. \& Skitka, L.J. (2012). Corporate social responsibility as a source of employee satisfaction, Research in Organizational Behavior, http://dx.doi.org/10.1016/j.riob.2012.11.002.

Cella-De-Oliveira, F. A. (2013). Indicators of organizational sustainability: A proposition from organizational competences. International Review of Management and Business Research, 2(4), 962-979.

Dan-Jumbo C. T. \& Akpan E. E. (2018). The promises and perils of multinational corporations: The Nigerian experience. International Journal of Management Science and Business Administration, 4(3), 71-76.

Elisa, W. (2002). Globalization, governance, and multinational enterprise responsibility: Corporate codes of conduct in the $21^{\text {st }}$ century. Citing Paul Hawken \& William McDonough, Seven Steps to Doing Good Business, INC., Nov. 1993, at 80.

Elkington J. (1999). Cannibals with forks: The triple bottom line of $21^{\text {st }}$ century business. Capstone Publishing Limited: Oxford.

European Commission (2002). Corporate social responsibility: A business contribution to sustainable development. Office for Official Publications of the European Communities.

Fontaine, M. (2013). Corporate social responsibility and sustainability: The new bottom line? International Journal of Business and Social Science, $4(4), 110-119$.

Freeman, R. E. (1984). Strategic management: A stakeholder approach. Marshfield, MA: Pitman.

Friedman, M. (1970). The social responsibility of business is to increase its profits. New York Times Magazine.

Gardberg, N. A., Zyglidopoulos, S. C., Symeou, P. C. and Schepers, D. H. (2017). The impact of corporate philanthropy on reputation for corporate social performance. Business and Society, doi:10.1177/0007650317694856

Geoffrey, P. L. (2001). The boundaries of strategic corporate social responsibility. Journal of Consumer Marketing, 18(7), 595-632.

Herrmann, K. K. (2004). Corporate social responsibility and sustainable development: The European Union Initiative as a case study. Indiana Journal of Global Legal Studies, 11(2), 205-232. 
Hosmer, L. T. (1995). Trust: The connecting link between organizational theory and philosophical ethics. Academy of Management Review, 20, 379-403.

Jensen, M. C. (2002). Value maximization, stakeholder theory, and the corporate objective function. Business Ethics Quarterly, 12, $235-256$.

Jones, T. M. (1995). Instrumental stakeholder theory: A synthesis of ethics and economics. Academy of Management Review, 20, 404-437.

Kesmodel, U. S. (2018). Cross-sectional studies - what are they good for? Acta Obstetricia et Gynecologica Scandinavica, 97(4) 388-393.

Khan, E. A., Dewan, M. N. A. \& Chowdhury, M. M. H. (2014). Development and validation of a scale for measuring sustainability factors of informal microenterprises. Entrepreneurship Research Journal, 5(4), 347-372.

Kim, C. H. \& Scullion, H. (2013). The effect of Corporate Social Responsibility (CSR) on employee motivation: A cross-national study. Poznań University of Economics Review. 13(2), 5-30.

Kotler, P. \& Armstrong, G. (2015). Principles of marketing (16 ${ }^{\text {th }}$ ed.) UK: Pearson Education, Limited.

Levitt, T. (1958). The dangers of social responsibility. Harvard Business Review, 36(5), 38-44.

Mahajan, P. (2011). Corporate social responsibility: A new wave in corporate governance. Available at SSRN: https://ssrn.com/abstract=1840601 or http://dx.doi.org/10.2139/ssrn.1840601

Martínez, P. \& del Bosque, I. R. (2013). CSR and customer loyalty: The roles of trust, customer identification with the company and satisfaction. International Journal of Hospitality Management, 35, 89-99.

McWilliams, A., Siegel, D. S., \& Wright, P. M. (2006). Corporate social responsibility: Strategic implications. Journal of Management Studies, 43(1), 1-18.

Montazeri, A., Talebpour, M., Andam R. \& Kazemnejad, A. (2017). Measuring corporate social responsibility in sport industry: Development and validation of measurement scale. Annals of Applied Sport Science, 5(2), 97-114.

Nambiar, A. N. (2010). Challenges in sustainable manufacturing. Proceedings of 2010 International Conference on Industrial Engineering and Operations Management, Dhaka, Bangladesh, 9-10.

Ndu, O. A. E. \& Agbonifoh, B.A. (2014). Corporate social responsibility in Nigeria: A study of the petroleum industry and the Niger Delta Area. International Review of Social Sciences and Humanities, 6(2), 214-238.

Orlitzky, M., \& Swanson, D. L. (2008). Toward integrative corporate citizenship: Research advances in corporate social performance. London, UK: Palgrave Macmillan.

Orlitzky, M., Siegel, D. S. \& Waldman, D.A (2011). Strategic corporate social responsibility and environmental sustainability. Business \& Society, 50(1), $6-27$.

Oyewole S. O. \& Adewale, D. O. (2016). Sustainable development and corporate social responsibility in Sub-Saharan Africa: Evidence from industries in Cameroon. Economies, 4(10), 1-15.

Park, S. H., Shin, W. S., \& Kim, K. J. (2019). Assessing a social responsibility model for sustainable company growth in the fourth industrial revolution. International Journal of Quality and Service Sciences, doi: 10.1108/IJQSS-11-2017-0108.

Pérez, A. \& del Bosque, I. R. (2015). An integrative framework to understand how CSR affects customer loyalty through identification, emotions and satisfaction. Journal of Business Ethics, 129(3), 571-84.

Pérez, A. \& del Bosque, I. R. (2015). Corporate social responsibility and customer loyalty: Exploring the role of identification, satisfaction and type of company. Journal of Service Marketing, 29(1), 15-25.

Peter, J., Daphne, C. \& David, H. (2014). E-retailers and environmental sustainability. International Journal of Management and Sustainability, $3(7), 457-468$.

Rosen, M. A. \& Kishawy, H. A. (2012). Sustainable manufacturing and design: Concepts, practices and needs. Sustainability, 4, 154-174.

Seetha, C. K. (2009). Stakeholder engagement and plastics waste, http://www.plasticbiz360.com/printarticle.aspx.

Wakhare, P. \& Borhade, S. (2018). Would mandatory CSR the panacea for sustainable development? Indian Perspectives. International Academic Journal of Business Management, 5(2), 10-22.

Werther Jr, W.B. \& Chandler, D. (2005). Strategic corporate social responsibility as global brand insurance. Business Horizons, 48(4), 317-324.

Wood, D. J. (2010). Measuring corporate social performance: A review. International Journal of Management Review, 12(1), 50-84. 


\section{APPENDIX}

This questionnaire is designed to gather information to enable me carry out research on the concepts of "strategic corporate social responsibility and organisational sustainability of multinational companies in Nigeria".

\section{Section A}

Please indicate the extent that you agree with the following items describing strategic corporate social responsibility. Scale: Strongly Disagree $=1$, Disagree $=2$, Neutral $=3$, Agree $=4$ and Strongly Agree $=5$

\begin{tabular}{|c|c|c|c|c|c|c|}
\hline \multicolumn{7}{|c|}{ STRATEGIC CORPORATE SOCIAL RESPONSIBILITY } \\
\hline S/N & Philanthropic Responsibilities & 1 & 2 & 3 & 4 & 5 \\
\hline 1 & My organization supports cultural and social events in the community & & & & & \\
\hline 2 & My organization gives financial and non-financial support to NGOs & & & & & \\
\hline 3 & My organization support activities related to health and wellness in the community & & & & & \\
\hline 4 & My organization helps to solve social and ethical problems in the community & & & & & \\
\hline 5 & My organization is committed to improving the welfare of the community & & & & & \\
\hline$S / N$ & Ethical Responsibilities & 1 & 2 & 3 & 4 & 5 \\
\hline 1 & Obeying the principle of fair play in the competition & & & & & \\
\hline 2 & Obeying ethical norm which society requires & & & & & \\
\hline 3 & Accountability to stakeholders' criticisms and demands & & & & & \\
\hline \multirow[t]{2}{*}{4} & Avoiding unethical behavior & & & & & \\
\hline & Legal Responsibilities & 1 & 2 & 3 & 4 & 5 \\
\hline 1 & Trying to implementation of rules and regulations & & & & & \\
\hline 2 & Respecting the rights of shareholders beyond the legal requirements & & & & & \\
\hline 3 & Respecting rules and regulations defined by law & & & & & \\
\hline 4 & Ensure that operation meets all legal standards & & & & & \\
\hline
\end{tabular}




\section{Section B}

To what extent do you agree with the following items describing your company's level of Sustainability?

Scale: $\quad$ Strongly Disagree $=1$, Disagree $=2$, Neutral $=3$, Agree $=4$ and Strongly Agree $=5$

\begin{tabular}{|c|c|c|c|c|c|c|}
\hline \multicolumn{7}{|c|}{ ORGANISATIONALSUSTAINABILITY } \\
\hline S/N & Economic Sustainability & 1 & 2 & 3 & 4 & 5 \\
\hline 1 & We see our firm is providing employment to us and others in the future. & & & & & \\
\hline 2 & Our firm's economic performance is at an acceptable level in terms of sales growth. & & & & & \\
\hline 3 & Our firm's economic performance is at an acceptable level in terms of income stability. & & & & & \\
\hline 4 & Our firm's economic performance is at an acceptable level in terms of return on investment. & & & & & \\
\hline S/N & Environmental Sustainability & 1 & 2 & 3 & 4 & 5 \\
\hline 1 & Our firm uses utilities (e.g., energy and water) in an environmental friendly manner & & & & & \\
\hline 2 & Our firm produces few wastes and emissions. & & & & & \\
\hline 3 & Our firm is concerned about waste management. & & & & & \\
\hline 4 & Our firm uses small space to set up and operate business. & & & & & \\
\hline \multirow[t]{2}{*}{5} & Our firm is concerned about hygienic factors. & & & & & \\
\hline & Social Sustainability & & & & & \\
\hline 1 & Our firm ensures basic needs for our family & & & & & \\
\hline 2 & Our firm enhances our social recognition in society. & & & & & \\
\hline 3 & Our firm improves our empowerment in society. & & & & & \\
\hline 4 & Our firm provides freedom and control over the course of our own lifestyle & & & & & \\
\hline
\end{tabular}

